\title{
The Inhalant Behaviour Ngelem of Punk Community Members
}

\section{Ridwan M. Thaha1', Ida Leida Mㄹ $^{2}$ Andi Selvi Yusnitasari², Ratna Jannatin MA ${ }^{1}$}

'Department of Health Promotion and Behavioural Science, Faculty of Public Health, Hasanuddin University, lndonesia; ${ }^{2}$ Department of Epidemiology, Faculty of Public Health, Hasanuddin University, Indonesia.

\section{ABSTRACT}

Introduction: Narcotics, Psychotropics, and other Addictive Substances (NAPZA) abuse is the use of one or several types of NAPZA regularly beyond the limit of medical indications, causing physical health, psychological and social functioning disorders

Objective: To know how punk communities influence the inhalant behaviour ngelem of punk community members.

Methods: Design of qualitative research conducted by observation and in-depth interviews toward 20 main informants and six key informants. Informants of this research are the punk community members in Makassar City.

Results: The punk community provided an inhalant stimulus and made members of the punk community give an operant conditioning by following the behaviour. They do not get rewards, but punishments such as prohibitions and suggestions to stop the inhalant behaviour ngelem from other punk community members. They get health problems as well, such as shortness of breath, dizziness, and headache. As a result, some informants decided to stop the activity, and some of them remained ngelem.

Conclusions: Lack of knowledge about the danger of inhalant behaviour ngelem makes them not refuse the stimulus, let alone invite fellow punk community members to refuse the behaviour.

Key Words: Inhalant behaviour ngelem, Stimulus, Punk community members

\section{INTRODUCTION}

Consumption of Narcotics, Psychotropics, and other Addictive Substances (NAPZA) affects the body, especially the brain/central nervous system, causing physical health, psychological and social function disorders due to habits, addiction, and dependency on NAPZA. NAPZA abuse is the use of one or several types of $N A P Z A$ regularly beyond the limit of medical indications, causing physical health, psychological and social functioning disorders. ${ }^{1}$ Based on the composition, inhalants or volatile substances are one type of addictive substance in the group of $N A P Z A$, which are very easy to be found generally. Products such as glue, gasoline, varnish, acetone for nail colour cleaning, paint thinners, correction pen, spray, and freon are examples of products containing volatile substances and are sold freely in stores or stalls. Misuse of these products can cause serious damage and even death. ${ }^{2}$

According to the report of Monitoring Future National Survey Result on Drug Use 1975-2016, it shows an increase of inhalant use on grade VIII, X and XII students in the United States in 1991, inhalant users were $7.6 \%$ and continued to increase until 1995 by $10.2 \%$ and subsequently decreased until 2016 to $2.6 \% .^{3}$ The results of a survey conducted among students aged 15-16 in almost 40 European countries, an average of $7 \%$, is known to say that they have used inhalant products. ${ }^{4}$ A systematic international review concludes that the most widely used drug among street children in low and middle-income countries is inhalants. ${ }^{5}$ In some provinces in Indonesia, the use of glue or commonly referred to as ngelem was mostly chosen in the first attempt of Narcotics, Psychotropics, and other Addictive Substances (NAPZA) used by students. Insufficient financial resources and the ease of access to this drug, because it is sold freely at stalls or shops, make it a choice for students. ${ }^{6}$ The research result conducted upon punk community on the streets of South Jakarta explains that the punks are very vulnerable to being affected by society problem and also contribute to the development of the social problem in their environments such as ngelem,

\section{Corresponding Author:}

Andi Selvi Yusnitasari, Department of Epidemiology, Faculty of Public Health, Hasanuddin University, Indonesia. Email: selvi.yusnitasari@unhas.ac.id

ISSN: 2231-2196 (Print)

Received: 15.08 .2020
ISSN: 0975-5241 (Online)

Revised: 30.09 .2020
Accepted: 28.10 .2020
Published: 07.12 .2020 
alcohol, drug, and narcotics abuse, free sex, prostitution, and criminal acts. ${ }^{7}$

In Makassar, the activity of ngelem is carried out by children aged 15-18 years. The average education level is an elementary school and has a low economic status. ${ }^{8}$ Besides, based on a researcher observation result, it is found that the activity of ngelem often carried out by the punks around Ujung Pandang District of Makassar City. Girls aged 15 years are found joined in a punk community. The number of punk community members reach hundreds. The inhalant behaviour ngelem is often carried out when they gather. This research aims to find out how the punk community influences the ngelem behaviour of the punk community members.

\section{MATERIALS AND METHOD}

This study used a qualitative approach with a phenomenological design. The study was conducted in Makassar City. Primary data collection was conducted in April 2018. The data were collected through interviews toward 26 informants consisting of 20 members of the punk community, and six relatives of the members. The method used for data collection was by direct interview, and observation was carried out as well for the data validation process. After the data have been collected, content analysis was carried out to conclude efforts to determine the characteristics of the message objectively and systematically, then interpreted and presented in the form of narration.

\section{RESULT}

Informants involved in this research were 26 people consisting of 20 members of the punk community. The age of the informants interviewed, namely, the youngest informant was 12 years old, and the oldest was 22 years old. This range of age is a period where people tend to look for who they truly are. The key informants in this study were six people, namely relatives of the community members, with the youngest age of 19 years old, and the oldest was 80 years old.

Judging from the educational background of the main informants, in this case, members of the punk community, two people did not graduate from elementary school, 11 people graduated elementary school, five people graduated from junior high school, and two people graduated from high school. The educational background of the relatives of a punk community member is one who graduated from elementary school, and five others graduated from high school. Stimulus or situation that obtained by the informant, which encourages ngelem behaviour. One of the things that can stimulate ngelem behaviour is the source of information. Based on informant answers, 16 out of 20 received information about ngelem in the punk community, while four others get information about ngelem from outside of the punk community. Informants in the punk community explained that they get information about ngelem by observing the behaviour of their friend who did ngelem, and then they concluded what they saw. The interview excerpts are as follows:

"From a friend. ngelem, illusions. It's like you can give it off the chakras. Imagining, like ..., like a dragonis passing by, can penetrate clouds, can do magic. Yes, he is a punk community member too."

(RI, 15 years old, Punk community member)

On the other hand, some informants got information about ngelem from outside of the punk community. The interview excerpts are as follows:

"Because of mingling with those kinds of people, people who ngelem too. Just a comingling, it has been so long since the age of 10 years old. I was not a punk kid yet. Not yet. Well, just kids around the neighbourhood."

$$
\text { (R, } 19 \text { years old, Punk community member) }
$$

Operant conditioning is a response to the environment. The response issued as a response toward the stimulus for $n g e-$ lem. Out of the 20 informants 16 informants are affected by the stimulus and eventually adopt ngelem as behaviour. While 4 informants rejected the stimulus to do ngelem. The informant who follows the ngelem behaviour admitted that he immediately tried when he was offered. The interview excerpts are as follows:

"I tried it. Even though at the very first place I did not want to. At first, I intended to just get drunk, but because I was offered so I joined them as well"

(MSS, 24 years old, Punk community member)

Even so, there were also informants who were not affected by the stimulus to ngelem. The interview excerpts are as follows:

"They invited me once, but I didn't respond to it. I left them be and I went busking. When I returned and I still saw them ngelem, using drugs, I directly went to bed. Even if it is my girlfriend, I am never afraid to be left behind, moreover if it's only my friends. I ever prohibit them to do ngelem by saying "don't do it, it is not good for you".

(E, 17 years old, Punk community member)

Health problems due to ngelem, which are detrimental to health consisting of clinical symptoms that are felt during and after ngelem in one day. Out of the 16 (sixteen) informants who did ngelem 12 of them had health problems. Whereas the informants who did not ngelem all answered 
that they had friends who had health problems from ngelem. Informants acquired different health problems due to ngelem. As quoted in the following interview:

"Yes, I ever felt my chest hurt after I did ngelem. It hurts like my chest was being pulled from inside and also I felt like I wanted to puke, but I didn't. I was experiencing a headache and something like "strip-strip".

(ARD, 20 years old, Punk community member)

Besides that, some informants did not get health problems due to ngelem behaviour. The interview excerpts are as follows:

"Nothing happened. nothing".

$$
\text { ( } \mathrm{T}, 18 \text { years old) }
$$

The ngelem behaviour is a person's response or reaction to sanctions and or rewards for ngelem behaviour. The intended behaviour mentioned is in the form of observable practices or actions. Out of the 16 informants who did ngelem 8 of them stopped ngelem after receiving sanctions, rewards, and health problems while 8 others continue to do ngelem activity. Meanwhile, the informant who initially refused the stimulus to ngelem up to the time of the interview still refused the stimulus. Informants who stopped ngelem for different reasons. As quoted in the following interview:

"I have stopped since I moved to Hertasning. Because I got no companion and also no one ever asked me out to do it. Also, to keep the name of punk."

(AR, 18 years old, Punk community member)

Also, some informants maintain the behaviour of ngelem after getting sanctions, rewards, and health problems. Although maintaining the behaviour of ngelem, there was still a change in each informant. Some increase the amount of glue inhaled and also some decrease it. Some did ngelem secretly.

"Yes, I still do it, if it runs out, I take again, again and again. Let's say up to 3 cans per day. Yes, the amount increase."

(ID, 17 years old, Punk community member)

\section{DISCUSSION}

The stimulus of informant's ngelem behaviour can be acknowledged from ngelem sources of information, solicitation of ngelem, the occurrence of ngelem activity in the community, and the existence of friends from the same punk community who engage in ngelem behaviour. The interview's result shows that most informants obtain information about ngelem from fellow members of the punk community. Punk community members do not distance themselves from fellow punks to discuss or exchange ideas. It is proven through the observation of researchers, who saw the intimacy built between punk communities. They do not hesitate to chat even though it is their first time meeting each other. This is due to the absence of castes or classes among the old-young, senior-junior, or superior-subordinate. So they are easier to get along with, even though most members of the punk community prefer to get along with their peers because of having the same topic of conversation or work. Punk communication's pattern is a communication of star pattern which means that all members are the same and have the same authority in conveying information both about ideologues, music, fashion, and experience. ${ }^{9}$

Most of the informants participate in the activity of ngelem. A supportive environment and the presence of stimulus to ngelem are making the informants vulnerable to being influenced by doing a similar thing. Although adolescents already have cognitive maturity, in reality, they have not been able to manage information received correctly. Consequently, adolescents are often uncontrolled. It cannot be denied since nowadays, teenagers receive information easily from peers, television, social media, and others. If this happens, adolescents are vulnerable to doing things that harm themselves and others. ${ }^{10}$

Most of the informants get health problems due to ngelem behaviour. It is caused by the content of benzene exposure within the glue. High concentrations of benzene exposure through inhalation or breathing can cause depression in the nerves system and can cause death. Initial symptoms can affect the nerves system in the form of drowsiness, dizziness, headaches, vertigo, and loss of consciousness. ${ }^{11}$

Some informants stop ngelem after getting sanctions, rewards, and health problems due to ngelem. It is figured from the interview's results and observations at the time of the study. The decision in reducing the use of addictive substances is caused by threats perceived by the informant. This corresponds with the Health Belief Model theory that one of the individual drivers acts to fight or treat the disease if he feels a vulnerability to illness. The informant did not know for certain the type of disease that threatened him, but symptoms of illness in the body due to the use of addictive substances. ${ }^{12}$ That children know for sure the negative effects of ngelem, but they like the intoxicating sensation generated by ngelem. ${ }^{13}$ Informants use addictive substances because as they stated, there are positive effects that are felt after consuming these substances.

\section{CONCLUSION}

The punk community gives a stimulus to ngelem and makes members of the punk community provide operant conditioning by following the behaviour. This does not make them 
get rewards but punishment in the form of prohibitions and suggestions to stop ngelem from other members of the punk community. Besides, they get health problems as well, such as shortness of breath, dizziness, and headache. Thus, some informants decided to stop ngelem and some of them remained ngelem. Members of the punk community did not think about the risk of ngelem before imitating or accepting the offer to ngelem. They are more concerned with a sense of brotherhood than their health. Lack of knowledge about the dangers of ngelem makes them not refuse the stimulus or ask for fellow members of the punk community to refuse the behaviour.

\section{ACKNOWLEDGEMENT}

Authors acknowledge the immense help received from the scholars whose articles are cited and included in references of this manuscript. The authors are also grateful to authors / editors / publishers of all those articles, journals and books from where the literature for this article has been reviewed and discussed.

Source(s) of Funding: No funding is involved.

Conflicting Interest: The authors declare no conflicting interest.

\section{REFERENCES}

1. Azmiyati SR. Gambaran penggunaan napza pada anak jalanan di Kota Semarang. J Kesehat Masy 2014;9(2):137-43.

2. Drug Enforcement Administration. Drugs of abuse: A DEA resource guide 2017 edition. 2017.
3. Johnston LD, O'Malley PM, Miech RA, Bachman JG, Schulenberg JE. Monitoring the Future national survey results on drug use, 1975-2016: Overview, key findings on adolescent drug use. Ann Arbor, Michigan: Institute for Social Research, The University of Michigan; 2017.

4. Kraus L, Nociar A. ESPAD report 2015: results from the European school survey project on alcohol and other drugs. Luxembourg: European Monitoring Centre for Drugs Drug Addic 2016.

5. Embleton L, Mwangi A, Vreeman R, Ayuku D, Braitstein P. The epidemiology of substance use among street children in resource-constrained settings: a systematic review and metaanalysis. Addiction 2013;108(10):1722-33.

6. Badan Narkotika Nasional. Hasil Survey Penyalahgunaan dan Peredaran Gelap Narkoba pada Kelompok Pelajar dan Mahasiswa di 18 Provinsi Tahun 2016. Pusat Penelitian Data dan Informasi Badan Narkotika Nasional. Jakarta; 2016.

7. Indaryanto AP. Identifikasi Keterpaan Dan Kontribusi Komunitas Punk Pada Penyakit Masyarakat Di Jakarta Selatan. Universitas Indonesia; 2011.

8. Azriful A, Ibrahim IA, Sulaiman Y. Gambaran Pengguna Narkoba Inhalasi (Ngelem) Pada Anak Jalanan di Kota Makassar Tahun 2015. Al-sihah Public Heal Sci J 2016;8(2).

9. Cahyanto PO. Pola Komunikasi Komunitas Punk dalam Penyebaran Paham Straight Edge (Studi pada Komunitas Punk Straight Edge di Malang). University of Muhammadiyah Malang; 2015.

10. Mukhtar M, Yusuf S, Budiamin A. Program Layanan Bimbingan Klasikal untuk Meningkatkan Self-Control Siswa. Psikopedagogia J Bimbing dan Konseling. 2016;5(1):1-16.

11. Susilowati B. Resiko Kesehatan Terhadap Pajanan Benzene Pada Pekerja Industri Sepatu Kulit di PIK Pulogadung Tahun 2011. Universitas Indonesia. University Indonesia; 2011.

12. Riskiyani S, Jannah M, Rahman A. Aspek Sosial Budaya Pada Konsumsi Minuman Beralkohol (Tuak) Di Kabupaten Toraja Utara. Media Kesehat Masy Indones. 2016;11(2):76-85.

13. Tamrin M, Nasir S, Riskiyani S. Studi perilaku" ngelem" pada remaja di kec. Paleteang kab. Pinrang tahun 2013. Universitas Hasanuddin; 2013. 